\title{
Aqueous and Microwave Assisted Extraction of Pectin from Grapefruit and Nagpur Mandarin
}

\author{
Sunil Kumar ${ }^{1 *}$, Ramesh Kumar ${ }^{1}$, P.C. Sharma ${ }^{2}$ and V.E. Nambi ${ }^{3}$ \\ ${ }^{1}$ ICAR-Central Institute of Post Harvest Engineering \& Technology, Abohar - 152116 (India) \\ ${ }^{2}$ YS Parmar University of Horticulture \& Forestry, Solan-173230 (India) \\ ${ }^{3}$ Indian Institute of Food Processing \& Technology, Thanjavur-613005 (India) \\ *Corresponding author
}

\section{A B S T R A C T}

Pectin is a complex polysaccharide with GRAS status which is increasingly finding its application in food and pharmaceutical industries. Two different methods (aqueous and microwave) were used for pectin extraction from the peels

Keywords

Aqueous extraction, Methoxyl percent, Microwave assisted extraction, Pectin, Yield

\section{Article Info}

Accepted:

17 June 2020

Available Online:

10 July 2020 of grapefruit (Citrus paradisi L.) and Nagpur mandarin (Citrus reticulata L.) using four different extraction times $(20,40,60$ and $80 \mathrm{~min})$, and with and without the use of cell wall degrading enzymes on yield and quality of extracted pectin. Pectin yield varied from 8.39 to $14.75 \%$ using aqueous method while it was significantly improved (8.19 to $18.58 \%$ ) when microwave assisted extraction was carried out using citric acid in extraction processes, irrespective of solvent concentration, incubation time and variety. Grapefruit peel produced slightly higher yield as compared to Nagpur mandarin. The optimium condition for pectin yield was found to be $60 \mathrm{~min}$ and 1:15 solid to solvent ratio for both varieties. Pectin isolated of grapefruit peel behaved as high methoxyl pectin while that of Nagpur mandarin was found be low methoxyl pectin based on the degree of esterification. Equivalent weight of pectin extracted from grapefruit was higher (659.93- 737.99) as compared to Nagpur mandarin. However, anhydrouronic acid content was found to be slightly higher (64.12- 74.45\%) for Nagpur mandarin as compared to grapefruit peel pectin.

\section{Introduction}

Pectins are methylated ester of polygalacturonic acid that contain 1,4-linked $\alpha$-D-galacturonic acid residues. It is a part of soluble dietary fibre and widely used in the food industry as a thickener, emulsifier, texturizer and stabilizer (Levigne et al.,
2002). Fresh weight of plant material contains $0.5-4.0 \%$ of pectin substances (Faravash and Ashtiani, 2008). These are the biopolymers found in the primary cell walls of most plant cells but most concentrated in citrus fruits (oranges, lemons, grapefruits) and apples. Worldwide currently commercial pectin is extracted from citrus peel and apple pomace, 
which are the by-products from juice/cider manufacturing (Chakraborty and Ray, 2011; Shaha et al., 2013). Pectin polysaccharides consist of 300-1000 chains of galacturonic acid units (Yeoh et al., 2008). The degree of esterification (DE) is one of the properties influencing pectin application as it determines the gelling nature of pectin. The DE percentage above $50 \%$ is classified as high methyl ester pectin (HMP) while those less than $50 \%$ is known as low methyl ester pectin (LMP) (Joye and Luzio, 2000). An HMP forms a gel in an acidic medium ( $\mathrm{pH}$ 2.0-3.5), if sucrose is present at a concentration $55 \%$. In contrast, an LMP generally forms a gel in the presence of $\mathrm{Ca}^{2+}$ within a larger $\mathrm{pH}$ range (2.0-7.0) whether sugar is present or not. Commercial LMPs are manufactured from HMPs by acid, alkali, ammonia, or enzymatic de-esterification (Yapo and Koffi, 2006).

The annual production of citrus fruits is about 11.58 million metric tones with an area of cultivation of about 10.24 lac hectares. India is ranked $3^{\text {rd }}$ amongst the top ten citrus fruits in terms of production after China and Brazil while in terms of productivity we fall at second last place just above Nigeria (Indian Horticulture Database, 2017). Fruit whether used for table purpose or juicing leads to a considerable amount of waste in the form of peel, rags etc. Also, percent average loss for citrus fruits is to the tune of $9.69 \%$ (Jha et al., 2015). Citrus waste comprises approximately $35-45 \%$ of the total fruit production, is highly perishable and seasonal, pose problem to the processing industries and pollution monitoring agencies (Puri et al., 2005). Meager level of processing and a sizeable post-harvest loss are responsible for a monetary loss of Rs 31,500/- crores annually in case of fruits and vegetables alone in India (Nanda et al., 2012; Jha et al., 2015; Rudra et al., 2015). By-product recovery from fruit residues can improve overall economics of processing units. Besides this, the problem of environmental pollution also can be reduced considerably (Londono-Londono et al., 2010).

Pectin extraction is the most important process in the pectin production. Mostly pectin extraction is done using hot diluted strong mineral acids like $\mathrm{HCl}, \mathrm{H}_{2} \mathrm{SO}_{4}$ etc. which are corrosive and always remain a potential threat to health, environment and overall economics due to generation of liquid waste by industrial processing (Lúcia et al., 2013). There are few reports of the extraction of pectin from remaining fruit peels using weak organic acid such as citric acid (Liew et al., 2014; Kulkarni and Vijayanand, 2010) which is health and environment friendly when compared to mineral acids. Therefore, an investigation was carried out at our laboratory to extract pectin employing citric acid, a safer alternative to inorganic acids using microwave as well as conventional aqueous extraction methods to extract pectin of grapefruit and Nagpur mandarin.

\section{Materials and Methods}

\section{Raw material}

Grapefruits were purchased from orchard of Regional Research Station, PAU, Abohar while Nagpur mandarin from local market. The fruits were washed; removed peel manually, dried under sunlight, and stored in cool and dry place till further use for pectin extraction. The dried peel was powdered and used for experimentation. All the experiments were performed using $100 \mathrm{~g}$ of raw material (dried peel powder) using aqueous as well as microwave assisted extraction methods for various time periods. Until stated otherwise, each experiment was replicated thrice.

\section{Microwave assisted extraction of pectin from citrus fruit residue}

The residue/peel powder was soaked in water and processed via 3 different routes. In one experiment, soaked residue powder was 
treated with 1000 units each of cellulase and xylanase for $2 \mathrm{~h}$ at $40{ }^{\circ} \mathrm{C}$ at native $\mathrm{pH}$. Pectin extraction (of enzyme treated samples) was performed at native $\mathrm{pH}$ while in another experiment; the enzyme treated broth was acidified using citric acid to $\mathrm{pH} 2.0$ and then extracted pectin. In the third route, soaked residue was acidified directly using citric acid to $\mathrm{pH} 2.0$ (omitting enzymatic degradation step) to extract pectin.

The experiments performed using $\mathrm{H}_{2} \mathrm{SO}_{4}$ (to $\mathrm{pH}$ 2.0) for pectin extraction served as control. After various pre-treatments, the broth was subjected to microwave energy (power level $900 \mathrm{~W}$ ) for 20, 40, 60 and 80 min. After microwave extraction and cooling, the pectin was precipitated from the broth using ethanol (1:1), filtered, drained and dried at $50^{\circ} \mathrm{C}$ overnight.

\section{Aqueous assisted extraction of pectin from citrus fruit residue}

For aqueous extraction, all the experiments were performed as during microwave extraction except that here after various pretreatments, the broth was subjected to aqueous extraction (temperature $95^{\circ} \mathrm{C}$ ) for 20 , 40, 60 and $80 \mathrm{~min}$. After aqueous extraction and cooling, the pectin was precipitated from the broth using ethanol (1:1), filtered, drained and dried at $50^{\circ} \mathrm{C}$ overnight.

\section{Purification of precipitated pectin}

The dried and clarified pectin samples were purified by immersing the crude pectin in ethanol: water mix $(1: 1)$ for $4 \mathrm{~h}$ followed by dehydrating with acetone for $4 \mathrm{~h}$. Both the steps were performed with constant shaking at $150 \mathrm{rpm}$ in orbital shaking incubator. Finally, the purified pectin was dried overnight at $50^{\circ} \mathrm{C}$, powdered and used for physic-chemical analysis.

\section{Physic-chemical analysis of citrus pectin}

For physic-chemical analysis, distilled water used was boiled for $15 \mathrm{~min}$ to eliminate dissolved $\mathrm{CO}_{2}$. Yield of pectin was estimated using precision weighing balance and expressed on per cent basis. Equivalent weight and methoxyl content were determined as per the procedure of Owens et al., (1952) as given in Ismail et al., (2012).

\section{Anhydrouronic acid (AUA) content}

The AUA content was calculated (Owens et al., 1952) by using the values of equivalent weight and methoxyl content $(\mathrm{MeO} \%)$ using the following expression:

AUA $\%=$

(meq of $\mathrm{NaOH}$ for free acid + meq of $\mathrm{NaOH}$ for $\mathrm{MeO} \%$ ) X 176 X100

Weight of sample (mg)

Where 176 is the molecular weight of AUA

Degree of esterification (DE)

The DE was calculated (Ismail et al., 2012) by using the values of $\mathrm{MeO} \%$ and AUA\% using the equation as hereunder:

$$
\mathrm{DE} \%=\frac{\mathrm{MeO} \% \times 176 \times 100}{31 \times \mathrm{AUA} \%}
$$

\section{Results and Discussion}

Preliminary standardization of solid to liquid ratio was done with respect to time of incubation and based on this, solid to liquid ratio used was maintained at 1:10 for 20 and $40 \mathrm{~min} ; 1: 15$ for $60 \mathrm{~min}$ and 1:20 for $80 \mathrm{~min}$ of incubation. Extraction of pectin was carried out using aqueous as well as microwave 
assisted extraction under various conditions from dried and powdered grapefruit and Nagpur manadarin peels. The high concentration of hydrogen ions presents in the solvent at acidic $\mathrm{pH}$ stimulated the hydrolysis of protopectin. At lower $\mathrm{pH}$, the highly hydrated carboxylate groups get repressed in huge hydrogen ion concentration and their charge repulsion is minimized. The addition of ethanol was able to dehydrate pectin so that the stability of its colloidal solution gets disturbed resulting in coagulated pectin (Megawati et al., 2015).

\section{Extraction of pectin from grapefruit peel residue}

The yield and other qualitative parameters of aqueous extracted grapefruit peel pectin are elaborated in Table 1. Among all treatment types, the highest \% yield $(14.75 \pm 0.19)$ was obtained for enzyme + citric acid combination with 60 min of incubation which was at par with only citric acid treatment $(14.67 \pm 0.64)$ for $60 \mathrm{~min}$ incubation. The enzyme + citric acid combination was nealy $26 \%$ higher than control treatment whose highest pectin yield was $10.91 \pm 0.11$ (Table 1). Only enzyme treatment with native $\mathrm{pH}$ yielded $1-3 \%$ pectin which was way below the optimum levels of pectin obtained of all other treatment types including control. The yield and other qualitative parameters of microwave assisted extracted grapefruit peel pectin are given in Table 2. Similar to aqueous extraction, the highest \% yield of pectin $(18.58 \pm 0.74)$ was obtained for enzyme + citric acid combination with $60 \mathrm{~min}$ of incubation which was at par with only citric acid treatment $(18.54 \pm 0.56)$ for $60 \mathrm{~min}$ of incubation. This implied that enzymatic pre-treatment was not so effective for enhancing pectin yield considerably from an optimum yield. The enzyme + citric acid combination was nealy $20 \%$ higher than control treatment $(14.84 \pm 0.69 \%)$ (Table 2). During microwave extraction, 20 and $40 \mathrm{~min}$ incubation times were insufficient to extract pectin of grapefruit peel for only enzyme treatment, however, at 60-80 min, extracted petin yield was also negligible $(0.26-0.31 \%)$ (Table 2). This might be due to absence of desired conditions for pectin breakdown at that $\mathrm{pH}$ or sole enzymatic treatment appeared to be too mild to yield any pectin. Pectin yield remained less at higher (alkaline or towards alkaline) $\mathrm{pH}$ as some pectin still remains attached to the cell wall components and unhydrolyzed (Udonne et al., 2016). Methoxyl content (\%) of extracted grapefruit peel pectin for both extraction methods (7.11-7.28\%) was more than $7 \%$ and degree of esterfication (60.37-63.57\%) was found to be more than $50 \%$, thus, indicating that the extracted pectin was high methoxyl in nature (Table 1 and 2). Equivalent weight of extracted grapefruit pectin was in the range of 659.93-737.99 while anhydrouronic acid content ranged from 64.97-67.46\% (Table 1 and 2). Among both types of extraction methods, microwave assisted extraction resulted in $21 \%$ more extraction of pectin compared to aqueous one for their optimized pectin yield at $60 \mathrm{~min}$ of incubation. Mohamed (2016) has reported pectin yield of $25 \%$ from grapefruit peel using a combination of $\mathrm{HNO}_{3}$ and $\mathrm{HCl}$ at temperature $80^{\circ} \mathrm{C}$ and $\mathrm{pH} 2.0$, for $60 \mathrm{~min}$ of aqueous mediated extraction. Methoxyl content of red and white type grapefruit was found to be 8.87 and 7.54 respectively, while the corresponding values for DE (\%) were reported to be 55.01 and $51.24 \%$, respectively. Thus, the grapefruit peel reported to be of high methoxyl in nature by Mohamed (2016). The AUA content was found to be $60.95 \%$ for both variants of grapefruit. Alexander and Sulebele (1980) reported pectin yield of $15-17 \%$ for Indian citrus peels, while Spanish grape fruit peels had corresponding yield of $30.7 \%$ as deduced by Iranzo et al., (1980). The differences in pectin obtained may be attributed to varietal differences and/or stage of maturity of the 
fruits. Sayah et al., (2016) carried out aqueous extraction of pectin from grapefruit peel using $0.1 \mathrm{M}$ each of citric acid and $\mathrm{H}_{2} \mathrm{SO}_{4}$ at $80^{\circ} \mathrm{C}$ for $60 \mathrm{~min}$. The highest pectin yield obtained from grapefruit peel was $33.63 \%$ using sulfuric acid, while using citric acid, pectin yield was $28.74 \%$. The corresponding values for $\mathrm{DE}(\%)$ were 74.49 and $75.53 \%$, respectively (Sayah et al., 2016). Khan et al., (2014) reported that maximum extraction $(22.55 \%)$ of pectin was done from grapefruit peel at temperature $120^{\circ} \mathrm{C}$ with $\mathrm{pH}-1.5$ for 30 min via aqueous $(\mathrm{HCl})$ mediated extraction. Methoxyl content and equivalent weight were found to be $11.77 \%$ and 992 respectively, of the extracted pectin. However, Aina et al., (2012) reported grapefruit peel to be of low methoxyl $(3.90 \%)$ in nature with equivalent weight of 293.6. Bagherian et al., (2011) inferred that highest total amount of pectin yield was found to be $27.81 \%(\mathrm{w} / \mathrm{w})$ for $6 \mathrm{~min}$ of extraction at $900 \mathrm{~W}$ using microwave extraction technique. Quoc et al., (2015) extracted pectin from pumelo (Citrus maxima) peels using tartaric acid and microwave energy. The yield of pectin obtained was $23.83 \%$ at $\mathrm{pH} 1.5$, rate of pumelo peel/solvent was $1 / 40$ for irradiation time of $9 \mathrm{~min}$ at $660 \mathrm{~W}$. Pectin extracted was rated as a high methoxyl pectin having DE of $92.75 \%$ with a low viscosity. Longer extraction time of microwave extraction (60 min) might be due to open type of microwave system. Microwave assisted extraction can be classified in to closed and open system i.e. closed system operates at high/ above atmospheric pressure in a sealed-vessel with different mode of microwave radiations while open system works below atmospheric pressure. Advancements in microwave extraction such as high-pressure microwaveassisted extraction have improved the extraction rate by allowing more penetration of solvent which is accomplished through breakage of cell structure (Sundari, 2015).

\section{Extraction of pectin from Nagpur mandarin peel residue}

Among all treatment types of aqueous extraction for orange peel, the highest $\%$ yield $(14.50 \pm 0.53)$ was obtained for enzyme + citric acid combination with $60 \mathrm{~min}$ of incubation which was slightly higher to only citric acid treatment $(12.97 \pm 0.48)$ for $60 \mathrm{~min}$ incubation. The pectin yield of enzyme + citric acid combination was nearly $31 \%$ higher compared to the best control treatment $(10.04 \pm 0.0 .37 \%)$ (Table 3). Only enzyme treatment with native $\mathrm{pH}$ failed to extract any pectin for all the parameters tested. This might be due to absence of desired conditions for pectin breakdown at that $\mathrm{pH}$ or sole enzymatic treatment appears to be too mild to yield any pectin. Pectin yield remained less at higher (alkaline or towards alkaline) $\mathrm{pH}$ as some pectin still remains attached to the cell wall components and un-hydrolyzed (Udonne et al., 2016). The yield and other qualitative parameters of microwave assisted extracted orange peel pectin are given in Table 4 . Similar to aqueous extraction, the highest \% yield of pectin $(18.56 \pm 0.55)$ was obtained for enzyme + citric acid combination with $60 \mathrm{~min}$ of incubation. The enzyme + citric acid combination was nealy $17 \%$ higher than control treatment where highest pectin yield was $15.38 \pm 0.28 \%$ (Table 4). During microwave extraction too, only enzyme treatment did not yield any pectin of Nagpur mandarin peel. Methoxyl content (\%) of extracted orange peel pectin for both extraction methods (5.54-6.03\%) was less than $7 \%$ and degree of esterification (45.76$49.15 \%$ ) was found to be less than $50 \%$, thus, indicating that the extracted pectin was low methoxyl in nature (Table 3 and 4). Equivalent weight of extracted orange pectin was in the range of 436.95-540.27 while anhydrouronic acid content ranged from 64.12-74.45\% (Table 3 and 4). 
Table.1 Yield of grapefruit peel pectin during aqueous extraction and its qualitative analysis

\begin{tabular}{|c|c|c|c|c|c|c|c|}
\hline $\begin{array}{c}\text { Combinatorial } \\
\text { treatment } \\
\text { type }\end{array}$ & $\begin{array}{c}\text { pH for } \\
\text { incubation }\end{array}$ & $\begin{array}{c}\text { Time of } \\
\text { incubation } \\
(\text { min })\end{array}$ & $\begin{array}{c}\text { Pectin yield } \\
\qquad(\%)\end{array}$ & $\begin{array}{c}\text { Methoxyl } \\
\text { content (\%) }\end{array}$ & $\begin{array}{l}\text { Equivalent } \\
\text { weight }\end{array}$ & $\begin{array}{l}\text { Anhydrouronic } \\
\text { acid content } \\
(\%)\end{array}$ & $\begin{array}{c}\text { Degree of } \\
\text { esterification } \\
(\%)\end{array}$ \\
\hline \multirow{4}{*}{$\begin{array}{l}* \text { Enzyme + } \\
\text { citric acid }\end{array}$} & \multirow[t]{4}{*}{2.0} & 20 & $8.39 \pm 0.24$ & $7.15 \pm 0.01$ & $674.26 \pm 5.72$ & $66.92 \pm 0.10$ & $60.69 \pm 0.14$ \\
\hline & & 40 & $13.43 \pm 0.31$ & $7.15 \pm 0.01$ & $671.29 \pm 3.97$ & $66.84 \pm 0.14$ & $60.70 \pm 0.17$ \\
\hline & & 60 & $14.75 \pm 0.19$ & $7.16 \pm 0.02$ & $668.23 \pm 5.16$ & $67.03 \pm 0.18$ & $60.64 \pm 0.22$ \\
\hline & & 80 & $13.14 \pm 0.37$ & $7.16 \pm 0.01$ & $666.76 \pm 5.63$ & $67.11 \pm 0.30$ & $60.60 \pm 0.15$ \\
\hline \multirow[t]{4}{*}{ Citric acid } & \multirow[t]{4}{*}{2.0} & 20 & $8.78 \pm 0.48$ & $7.14 \pm 0.01$ & $672.72 \pm 4.86$ & $66.74 \pm 0.18$ & $60.73 \pm 0.19$ \\
\hline & & 40 & $13.43 \pm 0.75$ & $7.14 \pm 0.01$ & $669.75 \pm 6.04$ & $66.86 \pm 0.22$ & $60.63 \pm 0.22$ \\
\hline & & 60 & $14.67 \pm 0.64$ & $7.15 \pm 0.02$ & $668.34 \pm 7.93$ & $66.97 \pm 0.41$ & $60.61 \pm 0.23$ \\
\hline & & 80 & $13.54 \pm 0.39$ & $7.16 \pm 0.03$ & $663.82 \pm 5.94$ & $67.21 \pm 0.38$ & $60.48 \pm 0.14$ \\
\hline \multirow[t]{4}{*}{ *Enzyme } & \multirow[t]{4}{*}{ Native } & 20 & $1.28 \pm 0.04$ & $7.12 \pm 0.02$ & $676.84 \pm 7.08$ & $66.47 \pm 0.34$ & $60.82 \pm 0.22$ \\
\hline & & 40 & $2.15 \pm 0.09$ & $7.14 \pm 0.02$ & $672.76 \pm 6.10$ & $66.76 \pm 0.22$ & $60.75 \pm 0.24$ \\
\hline & & 60 & $3.23 \pm 0.12$ & $7.15 \pm 0.03$ & $669.24 \pm 5.60$ & $66.94 \pm 0.33$ & $60.65 \pm 0.19$ \\
\hline & & 80 & $3.00 \pm 0.05$ & $7.15 \pm 0.02$ & $667.71 \pm 4.39$ & $66.99 \pm 0.10$ & $60.59 \pm 0.20$ \\
\hline \multirow{4}{*}{$\begin{array}{l}\text { Control } \\
\text { (sulphuric } \\
\text { acid) }\end{array}$} & \multirow[t]{4}{*}{2.0} & 20 & $4.13 \pm 0.10$ & $7.24 \pm 0.02$ & $737.99 \pm 10.26$ & $65.00 \pm 0.42$ & $63.21 \pm 0.28$ \\
\hline & & 40 & $5.28 \pm 0.22$ & $7.27 \pm 0.04$ & $733.00 \pm 6.02$ & $65.35 \pm 0.05$ & $63.16 \pm 0.30$ \\
\hline & & 60 & $9.76 \pm 0.10$ & $7.26 \pm 0.02$ & $724.16 \pm 6.14$ & $65.57 \pm 0.28$ & $62.83 \pm 0.18$ \\
\hline & & 80 & $10.91 \pm 0.11$ & $7.28 \pm 0.03$ & $720.80 \pm 9.03$ & $65.82 \pm 0.37$ & $62.79 \pm 0.28$ \\
\hline
\end{tabular}

*Enzyme = 1000 units each of cellulase and xylanase added to soaked peel powder and incubated at $40^{\circ} \mathrm{C}$ for $2 \mathrm{~h}$ prior to adding citric acid while in only enzyme treatment type, no citric acid was added after enzymatic pre-treatment; - means no yield; $\mathrm{n}=3$ (value $\pm \mathrm{SEm}$ ) 
Table.2 Yield of grapefruit peel pectin during microwave extraction (900W) and its qualitative analysis

\begin{tabular}{|c|c|c|c|c|c|c|c|}
\hline $\begin{array}{c}\text { Combinatorial } \\
\text { treatment } \\
\text { type }\end{array}$ & $\begin{array}{c}\text { pH for } \\
\text { incubation }\end{array}$ & $\begin{array}{c}\text { Time of } \\
\text { incubation } \\
(\text { min) }\end{array}$ & $\begin{array}{c}\text { Pectin yield } \\
(\%)\end{array}$ & $\begin{array}{c}\text { Methoxyl } \\
\text { content (\%) }\end{array}$ & $\begin{array}{c}\text { Equivalent } \\
\text { weight }\end{array}$ & $\begin{array}{l}\text { Anhydrouronic } \\
\text { acid content } \\
(\%)\end{array}$ & $\begin{array}{c}\text { Degree of } \\
\text { esterification } \\
(\%)\end{array}$ \\
\hline \multirow{4}{*}{$\begin{array}{l}* \text { Enzyme + } \\
\text { citric acid }\end{array}$} & \multirow[t]{4}{*}{2.0} & 20 & $14.30 \pm 0.61$ & $7.11 \pm 0.03$ & $675.32 \pm 7.05$ & $66.47 \pm 0.46$ & $60.70 \pm 0.13$ \\
\hline & & 40 & $17.61 \pm 0.67$ & $7.12 \pm 0.06$ & $671.39 \pm 9.11$ & $66.72 \pm 0.39$ & $60.61 \pm 0.42$ \\
\hline & & 60 & $18.58 \pm 0.74$ & $7.16 \pm 0.07$ & $663.38 \pm 7.11$ & $67.25 \pm 0.23$ & $60.44 \pm 0.45$ \\
\hline & & 80 & $18.02 \pm 0.37$ & $7.18 \pm 0.07$ & $659.93 \pm 5.97$ & $67.49 \pm 0.19$ & $60.40 \pm 0.44$ \\
\hline \multirow[t]{4}{*}{ Citric acid } & \multirow[t]{4}{*}{2.0} & 20 & $14.07 \pm 0.71$ & $7.12 \pm 0.05$ & $671.20 \pm 4.61$ & $66.68 \pm 0.39$ & $60.59 \pm 0.15$ \\
\hline & & 40 & $17.93 \pm 0.61$ & $7.11 \pm 0.04$ & $663.40 \pm 7.65$ & $66.84 \pm 0.20$ & $60.42 \pm 0.53$ \\
\hline & & 60 & $18.54 \pm 0.56$ & $7.14 \pm 0.04$ & $663.74 \pm 3.05$ & $67.08 \pm 0.13$ & $60.41 \pm 0.24$ \\
\hline & & 80 & $17.85 \pm 0.47$ & $7.18 \pm 0.05$ & $660.49 \pm 7.87$ & $67.46 \pm 0.60$ & $60.42 \pm 0.17$ \\
\hline \multirow[t]{4}{*}{ *Enzyme } & \multirow[t]{4}{*}{ Native } & 20 & - & - & - & - & - \\
\hline & & 40 & - & - & - & - & - \\
\hline & & 60 & $0.26 \pm 0.02$ & $7.12 \pm 0.05$ & $665.79 \pm 6.12$ & $66.94 \pm 0.17$ & $60.42 \pm 0.38$ \\
\hline & & 80 & $0.31 \pm 0.02$ & $7.15 \pm 0.05$ & $662.39 \pm 6.87$ & $67.21 \pm 0.12$ & $60.37 \pm 0.43$ \\
\hline \multirow{4}{*}{$\begin{array}{l}\text { Control } \\
\text { (sulphuric } \\
\text { acid) }\end{array}$} & \multirow[t]{4}{*}{2.0} & 20 & $9.52 \pm 0.78$ & $7.22 \pm 0.04$ & $734.90 \pm 8.73$ & $64.97 \pm 0.15$ & $63.06 \pm 0.40$ \\
\hline & & 40 & $14.70 \pm 0.56$ & $7.25 \pm 0.06$ & $730.66 \pm 7.33$ & $65.31 \pm 0.08$ & $63.57 \pm 1.07$ \\
\hline & & 60 & $14.84 \pm 0.69$ & $7.26 \pm 0.03$ & $716.77 \pm 8.71$ & $65.71 \pm 0.17$ & $62.76 \pm 0.39$ \\
\hline & & 80 & $14.71 \pm 0.24$ & $7.27 \pm 0.04$ & $718.45 \pm 7.94$ & $65.86 \pm 0.15$ & $62.70 \pm 0.36$ \\
\hline
\end{tabular}

*Enzyme $=1000$ units each of cellulase and xylanase added to soaked peel powder and incubated at $40^{\circ} \mathrm{C}$ for $2 \mathrm{~h}$ prior to adding citric acid while in only enzyme treatment type, no citric acid was added after enzymatic pre-treatment; - means no yield; $n=3$ (value \pm SEm) 
Table.3 Yield of orange peel pectin during aqueous extraction and its qualitative analysis

\begin{tabular}{|c|c|c|c|c|c|c|c|}
\hline $\begin{array}{l}\text { Combinatorial } \\
\text { treatment } \\
\text { type }\end{array}$ & $\begin{array}{l}\text { pH for } \\
\text { incubation }\end{array}$ & $\begin{array}{l}\text { Time of } \\
\text { incubation } \\
\text { (min) }\end{array}$ & $\begin{array}{l}\text { Pectin yield } \\
(\%)\end{array}$ & $\begin{array}{l}\text { Methoxyl } \\
\text { content }(\%)\end{array}$ & $\begin{array}{l}\text { Equivalent } \\
\text { weight }\end{array}$ & $\begin{array}{l}\text { Anhydrouronic } \\
\text { acid content }(\%)\end{array}$ & $\begin{array}{l}\text { Degree of } \\
\text { esterification } \\
(\%)\end{array}$ \\
\hline \multirow{4}{*}{$\begin{array}{l}* \text { Enzyme + } \\
\text { citric acid }\end{array}$} & \multirow[t]{4}{*}{2.0} & 20 & $8.66 \pm 0.34$ & $5.85 \pm 0.10$ & $450.93 \pm 2.62$ & $72.28 \pm 0.34$ & $45.92 \pm 0.55$ \\
\hline & & 40 & $12.10 \pm 0.47$ & $5.95 \pm 0.06$ & $446.12 \pm 5.51$ & $73.30 \pm 0.72$ & $46.09 \pm 0.25$ \\
\hline & & 60 & $14.50 \pm 0.53$ & $5.98 \pm 0.05$ & $441.88 \pm 3.46$ & $73.71 \pm 0.48$ & $46.06 \pm 0.11$ \\
\hline & & 80 & $14.49 \pm 0.71$ & $6.01 \pm 0.06$ & $436.95 \pm 3.40$ & $74.45 \pm 0.10$ & $45.83 \pm 0.44$ \\
\hline \multirow[t]{4}{*}{ Citric acid } & \multirow[t]{4}{*}{2.0} & 20 & $9.12 \pm 0.12$ & $5.84 \pm 0.03$ & $450.52 \pm 3.98$ & $72.30 \pm 0.44$ & $45.89 \pm 0.24$ \\
\hline & & 40 & $12.83 \pm 0.76$ & $5.91 \pm 0.04$ & $445.16 \pm 3.61$ & $73.14 \pm 0.56$ & $45.87 \pm 0.09$ \\
\hline & & 60 & $12.97 \pm 0.48$ & $5.93 \pm 0.04$ & $441.91 \pm 4.46$ & $73.53 \pm 0.21$ & $45.76 \pm 0.42$ \\
\hline & & 80 & $12.45 \pm 0.59$ & $6.03 \pm 0.03$ & $439.28 \pm 3.05$ & $74.37 \pm 0.45$ & $46.03 \pm 0.06$ \\
\hline \multirow[t]{4}{*}{ *Enzyme } & \multirow[t]{4}{*}{ Native } & 20 & - & - & - & - & - \\
\hline & & 40 & - & - & - & - & - \\
\hline & & 60 & - & - & - & - & - \\
\hline & & 80 & - & - & - & - & - \\
\hline \multirow{4}{*}{$\begin{array}{l}\text { Control } \\
\text { (sulphuric } \\
\text { acid) }\end{array}$} & \multirow[t]{4}{*}{2.0} & 20 & $3.07 \pm 0.31$ & $5.55 \pm 0.06$ & $540.27 \pm 3.75$ & $64.12 \pm 0.57$ & $49.11 \pm 0.11$ \\
\hline & & 40 & $6.83 \pm 0.37$ & $5.63 \pm 0.04$ & $532.97 \pm 5.42$ & $65.04 \pm 0.17$ & $49.15 \pm 0.42$ \\
\hline & & 60 & $7.75 \pm 0.34$ & $5.66 \pm 0.06$ & $524.54 \pm 4.18$ & $65.74 \pm 0.43$ & $48.88 \pm 0.32$ \\
\hline & & 80 & $10.04 \pm 0.37$ & $5.68 \pm 0.05$ & $515.52 \pm 4.03$ & $66.29 \pm 0.40$ & $48.64 \pm 0.11$ \\
\hline
\end{tabular}

*Enzyme $=1000$ units each of cellulase and xylanase added to soaked peel powder and incubated at $40^{\circ} \mathrm{C}$ for $2 \mathrm{~h}$ prior to adding citric acid while in only enzyme treatment type, no citric acid was added after enzymatic pre-treatment; - means no yield; $n=3$ (value \pm SEm) 
Table.4 Yield of orange peel pectin during microwave extraction (900W) and its qualitative analysis

\begin{tabular}{|c|c|c|c|c|c|c|c|}
\hline $\begin{array}{l}\text { Combinatorial } \\
\text { treatment } \\
\text { type }\end{array}$ & $\begin{array}{l}\text { pH for } \\
\text { incubation }\end{array}$ & $\begin{array}{l}\text { Time of } \\
\text { incubation } \\
(\mathrm{min})\end{array}$ & $\begin{array}{l}\text { Pectin yield } \\
(\%)\end{array}$ & $\begin{array}{l}\text { Methoxyl } \\
\text { content }(\%)\end{array}$ & $\begin{array}{l}\text { Equivalent } \\
\text { weight }\end{array}$ & $\begin{array}{l}\text { Anhydrouronic } \\
\text { acid content } \\
(\%)\end{array}$ & $\begin{array}{l}\text { Degree of } \\
\text { esterification } \\
(\%)\end{array}$ \\
\hline \multirow{4}{*}{$\begin{array}{l}* \text { Enzyme }+ \\
\text { citric acid }\end{array}$} & \multirow[t]{4}{*}{2.0} & 20 & $13.75 \pm 0.44$ & $5.91 \pm 0.04$ & $455.71 \pm 2.02$ & $72.20 \pm 0.43$ & $46.44 \pm 0.08$ \\
\hline & & 40 & $17.20 \pm 0.48$ & $5.87 \pm 0.03$ & $453.48 \pm 4.04$ & $72.20 \pm 0.53$ & $46.18 \pm 0.10$ \\
\hline & & 60 & $18.56 \pm 0.55$ & $5.94 \pm 0.07$ & $449.60 \pm 3.37$ & $72.78 \pm 0.55$ & $46.34 \pm 0.31$ \\
\hline & & 80 & $16.76 \pm 0.32$ & $5.97 \pm 0.04$ & $442.53 \pm 3.33$ & $73.74 \pm 0.16$ & $45.99 \pm 0.35$ \\
\hline \multirow[t]{4}{*}{ Citric acid } & \multirow[t]{4}{*}{2.0} & 20 & $8.19 \pm 0.51$ & $5.87 \pm 0.04$ & $453.66 \pm 2.53$ & $72.18 \pm 0.44$ & $46.17 \pm 0.06$ \\
\hline & & 40 & $10.69 \pm 0.50$ & $5.92 \pm 0.04$ & $449.59 \pm 2.83$ & $72.79 \pm 0.07$ & $46.12 \pm 0.31$ \\
\hline & & 60 & $16.56 \pm 0.66$ & $5.98 \pm 0.05$ & $445.84 \pm 4.16$ & $73.47 \pm 0.59$ & $46.18 \pm 0.22$ \\
\hline & & 80 & $15.20 \pm 0.67$ & $6.01 \pm 0.04$ & $442.58 \pm 4.78$ & $73.96 \pm 0.69$ & $46.18 \pm 0.12$ \\
\hline \multirow[t]{4}{*}{ *Enzyme } & \multirow[t]{4}{*}{ Native } & 20 & - & - & - & - & - \\
\hline & & 40 & - & - & - & - & - \\
\hline & & 60 & - & - & - & - & - \\
\hline & & 80 & - & - & - & - & - \\
\hline \multirow{4}{*}{$\begin{array}{l}\text { Control } \\
\text { (sulphuric } \\
\text { acid) }\end{array}$} & \multirow[t]{4}{*}{2.0} & 20 & $12.13 \pm 0.26$ & $5.57 \pm 0.06$ & $532.95 \pm 5.03$ & $64.71 \pm 0.63$ & $48.87 \pm 0.03$ \\
\hline & & 40 & $13.14 \pm 0.38$ & $5.54 \pm 0.05$ & $529.81 \pm 4.68$ & $64.71 \pm 0.08$ & $48.65 \pm 0.44$ \\
\hline & & 60 & $14.48 \pm 0.10$ & $5.61 \pm 0.04$ & $522.28 \pm 7.91$ & $65.55 \pm 0.45$ & $48.60 \pm 0.50$ \\
\hline & & 80 & $15.38 \pm 0.28$ & $5.65 \pm 0.06$ & $516.11 \pm 3.93$ & $66.23 \pm 0.22$ & $48.43 \pm 0.42$ \\
\hline
\end{tabular}

*Enzyme $=1000$ units each of cellulase and xylanase added to soaked peel powder and incubated at $40^{\circ} \mathrm{C}$ for $2 \mathrm{~h}$ prior to adding citric acid while in only enzyme treatment type, no citric acid was added after enzymatic pre-treatment; - means no yield; $n=3$ (value \pm SEm). 
Among both types of extraction methods, microwave assisted extraction resulted in $22 \%$ more extraction of pectin compared to aqueous one for their optimized pectin yield at $60 \mathrm{~min}$ of incubation. Yadav et al., (2015) found that pectin extraction (aqueous) from orange peel was optimum with extraction conditions: $85^{\circ} \mathrm{C}$ (temperature), $2.0(\mathrm{pH})$ and $60 \mathrm{~min}$ (time of incubation). Equivalent weights for control $(\mathrm{HCl})$ and citric acid treatments were found to be 625 and 416, respectively. Devi et al., (2014) carried out pectin extraction from orange peel using citric and nitric acid for different time, temperature and $\mathrm{pH}$ combinations and found $80^{\circ} \mathrm{C}$ temperature and $1.5 \mathrm{pH}$ for an incubation time of 60 min to be optimum conditions for pectin extraction. Methoxyl content of extracted pectin was 5.89 (citric acid) and 5.58 (nitric acid). Khan et al., (2015) extracted pectin form sweet orange using aqueous extraction method and reported a yield of $21 \%$ using extraction conditions of $70^{\circ} \mathrm{C}$ temperature and $2.5 \mathrm{pH}$ with $30 \mathrm{~min}$ of incubation. The extracted pectin had methoxyl content of nearly 70\%. Similarly, Aina et al., (2012) reported orange peel to be of low methoxyl $(5.79 \%)$ in nature with equivalent weight of 534. Luzio (2008) extracted pectin form orange peel (albedo) using closed vessel reactor heated with microwave irradiation. The highest yield was $17 \%$ at $110^{\circ} \mathrm{C}$ for $2 \mathrm{~min}$ at $\mathrm{pH}$ 1.7. Degree of methoxylation was $50.3 \%$ for the same. Mohamed and Hasan (1995) extracted pectin from green and yellow orange peels and found total pectin to be 16.06 and $14.48 \%$, respectively with corresponding degree of esterification 72.5 and $73.8 \%, \quad$ respectively. The anhydrogalacturonic acid content was found 69.49 and $68.99 \%$ respectively, for green and yellow type peel while the corresponding equivalent weight was estimated to be 920.73 and 974.60, respectively. Similarly, Yeoh et al., (2008) used microwave extraction of pectin for orange peel for 15 min extraction period at various $\mathrm{pH}$ values $(1.5,2.0,5.5$ and 10.0). Maximum pectin $(5.27 \%)$ was extracted at pH 1.5. Megawati et al., (2015) extracted pectin from Balinese orange peel via microwave extraction and found an optimum yield of $40.5 \%$ with a power level of $300 \mathrm{~W}$ and extraction time of $20 \mathrm{~min}$.

\section{Acknowledgements}

The work being submitted for publication is the output of institute project no. 11176 and the authors are thankful to Indian Council of Agricultural Research for research funding through institute project. Authors are also thankful to $\mathrm{M} / \mathrm{s}$ Advanced Enzymes Technologies Limited, Thane, India, for providing complimentary samples of enzymes, cellulase and xylanase for this research.

\section{References}

Aina, V.O., Barau, M.M., Mamman, O.A., Zakari, A., Haruna, H., Umar, M.S.H. and Abba, Y.B. (2012). Extraction and characterization of pectin from peels of lemon (Citrus limon), grape fruit (Citrus paradisi) and sweet orange (Citrus sinensis). British J. Pharmacol. Toxicol. 3(6): 259-262.

Alexader, M.M. and Sulebele, G.A. (1980). Characterisation of pectins from Indian citrus peels. J. Food Sci. Technol. 17: 180182.

Bagherian, H., Ashtiani, F. Z., Fouladitajar, A. and Mohtashamy, M. (2011). Comparisons between conventional, microwave and ultrasound-assisted methods for extraction of pectin from grapefruit. J. Chem. Engg. Processing: Process Intensification. 50 (11-12): 12371243.

Chakraborty, A. and Ray, S. (2011). Development of a process for the extraction of pectin from citrus fruit 
wastes viz. lime peel, spent guava extract, apple pomace etc. Internet J. Food Safety. 13: 391-397.

Devi, W.E., Shukla, R.N., Abraham, A., Jarpula, S. and Kaushik, U. (2014). Optimized extraction condition and characterization of pectin from orange peel. Int. J. Res. Engg. Adv. Technol. 2(2): 1-9.

Faravash, R.S. and Ashtiani, F.Z. (2008). The influence of acid volume, ethanol-toextract ratio and acid-washing time on the yield of pectic substances extraction from peach pomace. Food Hydrocolloids. 22: 196-202.

Indian Horticulture Database. (2017). nhb.gov.in/area-pro/Indian $\% 20$

Horticulture\%202017.pdf. (Retrieved on date 21/08/2018).

Iranzo, R.J., Barandalla, P.I. and Miralles, M.C. (1980). Preparation of dried peel for pectin from varieties of mandarin, grapefruit, bitter orange and lemon grown in Spain. Revista de Agroquimica Y Technologin de Alimentes. 20(13): 399402.

Ismail, N.S.M., Ramli, N., Hani, N.M. and Meon, Z. (2012). Extraction and characterization of pectin form dragon fruit (Hylocereus polyrhizus) using various extraction conditions. Sains Malaysiana. 41: 41-45.

Jha, S.N., Vishwakarma, R.K., Rai, A., Ahmed, T. and Dixit, A.K. (2015). Assessment of quantitative harvest and post-harvest losses of major crops and commodities in India. ICAR-AICRP on PHT, ICAR-CIPHET, Ludhiana.

Joye, D.D. and Luzio, G.A. (2000). Process for selective extraction of pectins from plant material by different $\mathrm{pH}$. Carbohydrate Polymers. 43: 337-342.

Khan, A.A., Butt, M.S., Randhawa, M.A., Karim, R., Sultan, M.T. and Ahmed, W. (2014). Extraction and characterization of pectin from grapefruit (Duncan cultivar) and its utilization as gelling agent. Int. Food Res. J. 21(6): 2195-2199.

Khan, M., Bibi, N. and Zeb, A. (2015). Optimization of process conditions for pectin extraction from Citrus peel. Sci. Technol. Development. 34(1): 9-15.

Kulkarni, S.G. and Vijayanand, P. (2010). Effect of extraction conditions on the quality characteristics of pectin from passion fruit peel (Passiflora edulis F. Flavicarpa L.). Food Sci. Technol. 43: 1026-1031.

Levigne, S., Ralet, M.C. and Thibault, J.F. (2002). Characterization of pectins extracted from fresh sugar beet under different conditions using an experimental design. Carbohydrate Polymers. 49: 145153.

Liew, S.Q., Chin, N.L. and Yusof, Y.A. (2014). Extraction and characterization of pectin from passion fruit peels. Agriculture and Agricultural Sciences Procedia. 2: 231-236.

Londono-Londono, J., de Lima, V.R., Lara, O., Gil, A., Pasa, T.B.C., Arango, G.J. and Pineda, J.R.R. (2010). Clean recovery of antioxidant flavonoids from citrus peel: Optimizing an aqueous ultrasoundassisted extraction method. Food Chem. 119: 81-87.

Lúcia, C.V., Reinaldo, F.T. and Carmen, L.O.P. (2013). Extraction and characterization of pectin from cacao pod husks (Theobroma cacao L.) with citric acid. J. Food Sci. Technol. 49: 108-116.

Luzio, G.A. (2008). Microwave release of pectin from orange peel albedo using a closed vessel reactor system. Proceedings of Florida State Horticultural Sciences. 121: 315-319.

Megawati, Widiastuti, D.R., Jannah, R.A. and Rahayuningtiyas, I. (2015). Microwave assisted extraction of pectin form Balinese orange peel using different power levels and times. Proceeding of International Conference on Green Technology, 
Semarang, Indonesia, IIC, pp 7-10 (eic.ft.unnes.ac.id).

Mohamed, H. (2016). Extraction and characterization of pectin from grapefruit peels. MOJ Food Processing Technol. 2(1): $\quad$ Pages $9 ;$ doi: 10.15406/mojfpt.2016.02.00029.

Mohamed, S. and Hasan, Z. (1995). Extraction and characterization of pectin from various tropical agrowastes. ASEAN Food J. 10: 43-50.

Nanda, S.K., Vishwakarma, R.K., Bathla, H.V.L., Rai, A. and Chandra, P. (2012). Harvest and post-harvest losses of major crops and livestock produce in India. AICRP on PHT, CIPHET (ICAR), Ludhiana.

Owens, H.S., McCready, R.M., Shepard, A.D., Schultz, T.H., Pippen, E.L., Swenson, H.A., Miers, J.C., Erlandsen, R.F. and Maclay, W.D. (1952). Methods used at Western Regional Research Laboratory for Extraction of Pectic Materials. USDA Bur. Agric. Ind. Chem. pp 9.

Puri, M., Kaur, H. and Kennedy, J.F. (2005). Covalent immobilization of naringinase for the transformation of a flavonoid. J. Chem. Technol. Biotechnol. 80: 11601165.

Quoc, L.P.T., Huyen, V.T.N., Hue, L.T.N., Thuan, N.H.D., Tam, N.T.T., Thuan, N.N. and Duy, T.H. (2015). Extraction of pectin from Pomelo (Citrus maxima) peels with the assistance of microwave and tartaric acid. Int. Food Res. J. 22(4): 1637-1641.

Rudra, S.G., Nishad, J., Jakhar, N. and Kaur, C. (2015). Food industry waste: Mine of nutraceuticals. Int. J. Sci. Env. Technol. 4(1): 205-229.

Sayah, M.Y., Chabir, R., Benyahia, H., Kandri, Y.R., Chahdi, F.O., Touzani, H. and Errachidi, F. (2016). Yield, esterification degree and molecular weight evaluation of pectins isolated from orange and grapefruit peels under different conditions. PLOS One, 11(9): Pages 16; e0161751. doi:10.1371/journal.pone.0161751.

Shaha, R.K., Nayagi, Y., Punichelvana, A.P. and Afandi, A. (2013). Optimized extraction condition and characterization of pectin for Kaffir lime (Citrus hystrix). Res. J. Agric. Forestry Sci. 1(2): 1-11.

Sundari, N. (2015). Extraction of pectin from waste peels: A review. Res. J. Pharma. Biol. Chem. Sci. 6(2): 1842-1848.

Udonne, J.D., Ajani, O.O. and Akinyemi, O.P. (2016). A comparative study of extraction of pectin from wet and dried peels using water based and microwave methods. Int. J. Sci. Engg. Res. 7: 416432.

Yadav, S.R., Khan, Z.H., Kunjwani, S.S. and Mular, S.M. (2015). Extraction and characterization of pectin from different fruits. Int. J. Appl. Res. 1(9): 91-94.

Yapo, B.M. and Koffi, K.L. (2006). Yellow passion fruit rind- A potential source of low-methoxyl pectin. J. Agric. Food Chem. 54: 2738-2744.

Yeoh, S., Shi, J. and Langrish, T.A.G. (2008). Comparisons between different techniques for water-based extraction of pectin from orange peels. Desalination. 218: 229-237.

\section{How to cite this article:}

Sunil Kumar, Ramesh Kumar, P.C. Sharma and Nambi, V.E. 2020. Aqueous and Microwave Assisted Extraction of Pectin from Grapefruit and Nagpur Mandarin. Int.J.Curr.Microbiol.App.Sci. 9(07): 1938-1949. doi: https://doi.org/10.20546/ijcmas.2020.907.221 